\title{
Performance of Cucumber (Cucucmis sativus L.) as Influenced by Humic Acid and Micro Nutrients Application under Polyhouse Condition
}

\author{
Somendra Meena*, K.D. Ameta, R.A. Kaushik, Shankar Lal Meena and Madhu Singh \\ Rajasthan College of Agriculture, Maharana Pratap University of Agriculture and \\ Technology, Udaipur, Rajasthan, India \\ *Corresponding author
}

\section{A B S T R A C T}

\begin{tabular}{|l|}
\hline Key w o r d s \\
Cucumber, \\
Humic acid, \\
Micronutrient \\
and yield.
\end{tabular}

An experiment was conducted at Hi-tech unit of Rajasthan College of Agriculture, MPUAT, Udaipur, Rajasthan to study the varietal performance of cucumber as influenced by different application of humic acid and micronutrient treatments. There were seven treatments of humic acid and micro nutrients applications. The experiment was laid out in completely randomized design with three replications during 2014-15. Observations were recorded for different characteristics related to vegetative, yield and yield attributing and moisture content. Treatment $\mathrm{T}_{7}[(\mathrm{RDF}+$ humic acid $10 \mathrm{~kg} / \mathrm{ha}$ soil application + humic acid $0.1 \%$ foliar spray + micronutrient mixture foliar spray $(0.5 \% \mathrm{Zn}+0.2 \% \mathrm{~B}+0.5 \% \mathrm{Mn})]$ was best in regards vegetative traits viz. vine length $(\mathrm{cm})$, number of branch per plant and leaf area $\left(\mathrm{cm}^{2}\right)$. Yield and yield attributing characteristics like number of fruits per vine, fruit weight $(\mathrm{g})$, fruit length $(\mathrm{cm})$, fruit diameter $(\mathrm{cm})$, volume of fruit $(\mathrm{cc})$, yield per plant $(\mathrm{kg})$ and yield per square meter $(\mathrm{kg})$ were significantly influenced by effect of humic acid and micronutrients.

\section{Introduction}

Cucumber (Cucumis sativus L.) a popular warm season vegetable, belongs to family cucurbitaceae and grows throughout the world under tropical and subtropical conditions. It is said to be the native of northern India (Pursglove, 1969) whereas China is considered as one of the secondary centers of genetic diversification (De Candolle, 1882). The fruits of cucumbers possesses various medicinal properties e.g. cooling effect, prevents constipation, checks jaundice and indigestion (Nandkarni, 1927). Nutritionally $100 \mathrm{~g}$ of edible portion of cucumber contains $96.3 \mathrm{~g}$ moisture, $2.5 \mathrm{~g}$ carbohydrates, $0.4 \mathrm{~g}$ protein, $0.1 \mathrm{~g}$ fat, $0.3 \mathrm{~g}$ minerals, $10 \mathrm{mg}$ calcium, $0.4 \mathrm{~g}$ fiber and traces of vitamin $\mathrm{C}$ and iron. In Rajasthan, the approximate area under this crop is around 4550 hectares with total production of about 14323 metric tons, whereas in India, cucumber is cultivated in an area of 18,000 hectares with a production of 1,20,000 tonnes (Anjanappa et al., 2012)

Cucumber is most popular crop growing under protected conditions due to its short life cycle. Parthenocarpic and gynoecious cucumber cultivars increase the potential to yield a high fruit load in controlled environments resulting in a high harvest index. Plants exhibiting a high harvest index will more efficiently use the limited growing area in a growth chamber. Polyhouse 
cultivation is still a new and emerging trend for growing vegetables in India. India, being a vast country with diverse and extreme agro climatic conditions, the protected vegetable cultivation technology can be utilized for year round production of high value vegetable crops, with more yield. Protected cultivation actually achieves higher water and nutrient use efficiencies. Increasing photosynthetic efficiency and reduction in transpiratory losses are added advantages of protected cultivation. Both of these factors are of vital importance for healthy and luxuriant growth of crop plants. This technology is highly suitable for farmers in peri-urban areas of the country, especially in northern plains of India. Successful protected cultivation requires careful planning and attention including nutrient management to produce economic yield of good quality. Humic acid, as a commercial product contains $44-58$ per cent C, 42-46 per cent $\mathrm{O}, 6-8$ per cent $\mathrm{H}$ and $0.5-4$ per cent $\mathrm{N}$, as well as many other elements (Larcher, 2003) which improves soil fertility and increases the availability of nutrient elements by holding them on mineral surfaces. The humic substances are mostly used to remove or decrease the negative effects of chemical fertilizers from the soil and have a major effect on plant growth, as shown by many scientists (Ghabbour and Davies, 2001). Humic substances can stabilize soil structure (Piccolo and Mbagwu, 1990) and increase cation exchange. Root growth enhancement has been attributed to improved soil structure, stimulation of soil microflora, and plant growth regulator effects (Chen and Aviad, 1990). The availability of nutrients from the humic substances, chelation of nutrients by the humates (Stevenson, 1991), or through more complex physiological interactions (Vaughan et al., 1985).

To improve the yield and quality of the product, it is necessary to pay attention on the optimum balanced use of nutrients through fertilizer application. Plants require mineral elements for normal growth and development. Plants requirements to essential for the normal life processes of plants and are needed in very small amounts are called trace elements or minor elements such as boron, zinc, manganese etc. In this study, we determine the influence of exogenously applied humic acid (HA) and micronutrients on growth and yield of cucumber grown in a greenhouse.

\section{Materials and Methods}

The experiment was conducted under naturally ventilated poly house at Hi-tech Horticulture Unit, Rajasthan College of Agriculture, Udaipur (Rajasthan) during 2014-15. The trial was laid out in Completely Randomized Design with three replications. The polyhouse was covered with aluminate sheet and ultra violet stabilized low density polyethylene sheet having 200 micron thickness with provision of foggers. The experiment was comprised of seven treatments RDF (control)- $\mathrm{T}_{1}, \mathrm{RDF}+$ Humic acid $10 \mathrm{~kg} / \mathrm{ha}$ (soil application)-T $2, \mathrm{RDF}+$ Humic acid $0.1 \%$ (foliar spray)- $\mathrm{T}_{3}, \mathrm{RDF}+$ Humic acid $10 \mathrm{~kg} / \mathrm{ha}+$ Humic acid $0.1 \%$ (foliar spray)-T $4, \mathrm{RDF}+$ Humic acid $10 \mathrm{~kg} / \mathrm{ha}$ + micronutrient mixture (foliar spray) $-\mathrm{T}_{5}$, $\mathrm{RDF}+$ Humic acid $0.1 \%+$ micronutrient mixture (foliar spray)- $\mathrm{T}_{6}$ and $\mathrm{RDF}+$ Humic acid $10 \mathrm{~kg} / \mathrm{ha}+$ Humic acid $0.1 \%+$ micronutrient mixture (foliar spray) $-\mathrm{T}_{7}$. For green house cultivation of cucumber, the seedlings were raised on soil-less media (Mixture of vermiculite, perlite and cocopith) in plug trays having cells of $2 "$ in size. Two weeks old seedlings at 2-3 true leaf stage were transplanted. The recommended dose of fertilizer viz. nitrogen@120 kg/ha, phosphorus@80 kg/ha and potash@80 kg/ha were applied through water soluble fertilizer. As per treatments soil application of humic acid was applied through drenching after 
transplanting and foliar spray of humic acid was applied after 30 days, whereas foliar spray of micronutrient mixture was applied 60 day after transplanting. All the cultural practices including irrigation and hoeing were carried out as per the standard commercial procedures. Spraying for pests and diseases were applied whenever it appeared necessary throughout the growing season. Plants were vertically trained with plastic ropes. Data were recorded for vine length $(\mathrm{m})$, leaf area $\left(\mathrm{cm}^{2}\right)$, number of branches per vine, number of fruits per vine, fruit weight $(\mathrm{g})$, fruit length $(\mathrm{cm})$, fruit volume $(\mathrm{cc})$, fruit diameter $(\mathrm{cm})$ and yield per vine $(\mathrm{kg})$ and moisture content (per cent) from randomly selected five tagged plants of each treatment and further analyzed. All data were subjected to analysis of variance to determine the treatment effects.

\section{Results and Discussion}

Results showed (Table: 1 and 2) that application of humic acid and micronutrients significantly affect all the characters studied. Results obtained indicated significant differences for vine length having a range of $216.33 \mathrm{~cm}\left(\mathrm{~T}_{1}\right)$ to $304.33 \mathrm{~cm}\left(\mathrm{~T}_{7}\right)$, similar trained were also obtained by Boehme et al., (2005).

Table.1 Effect of humic acid and micronutrients on fruit parameter and yield at the time of last harvesting

\begin{tabular}{|l|c|c|c|c|c|c|c|}
\hline S.No. & Detail of Treatment & $\begin{array}{c}\text { Fruit } \\
\text { weight } \\
(\mathbf{g})\end{array}$ & $\begin{array}{c}\text { Fruit } \\
\text { length } \\
(\mathbf{c m})\end{array}$ & $\begin{array}{c}\text { Fruit } \\
\text { diameter } \\
(\mathbf{c m})\end{array}$ & $\begin{array}{c}\text { Fruit } \\
\text { volume } \\
(\mathbf{c c})\end{array}$ & $\begin{array}{c}\text { Yield } \\
\text { (kg/vine) }\end{array}$ & $\begin{array}{c}\text { Yield } \\
(\mathbf{k g} / \mathbf{s q m})\end{array}$ \\
\hline $\mathbf{1 .}$ & RDF (control) & 115.86 & 15.78 & 2.86 & 101.78 & 2.88 & 11.48 \\
\hline $\mathbf{2 .}$ & $\begin{array}{c}\text { RDF+ Humic acid 10 } \\
\text { kg/ha (soil application) }\end{array}$ & 116.97 & 16.45 & 2.88 & 102.53 & 2.98 & 12.50 \\
\hline $\mathbf{3 .}$ & $\begin{array}{c}\text { RDF+ Humic acid 0.1 } \\
\text { \% (foliar spray) }\end{array}$ & 117.06 & 16.77 & 2.87 & 103.41 & 3.11 & 13.10 \\
\hline $\mathbf{4 .}$ & $\begin{array}{c}\text { RDF+ Humic acid 10 } \\
\text { kg/ha + Humic acid 0.1 } \\
\text { \% (foliar spray) }\end{array}$ & 119.12 & 17.10 & 2.89 & 104.98 & 3.24 & 13.88 \\
\hline $\mathbf{5 .}$ & $\begin{array}{c}\text { RDF+ Humic acid 10 } \\
\text { kg/ha + micronutrient } \\
\text { mixture (foliar spray) }\end{array}$ & 121.86 & 17.06 & 2.95 & 108.61 & 3.66 & 14.11 \\
\hline $\mathbf{6 .}$ & $\begin{array}{c}\text { RDF + Humic acid } \\
\text { 0.1\% + micronutrient } \\
\text { mixture (foliar spray) }\end{array}$ & 123.00 & 17.39 & 3.10 & 107.07 & 3.44 & 14.02 \\
\hline $\mathbf{7 .}$ & $\begin{array}{c}\text { RDF+ Humic acid 10 } \\
\text { kg/ha + Humic } \\
\text { acid0.1\%+micronutrient } \\
\text { mixture }\end{array}$ & 125.00 & 17.50 & 2.96 & 109.71 & 4.01 & 15.98 \\
\hline $\mathbf{8 .}$ & CD 5\% & 1.26 & 0.25 & 0.05 & 0.27 & 0.06 & 1.51 \\
\hline
\end{tabular}


Table.2 Effect of humic acid and micronutrients on Vine length, Number of branches per plant, Leaf area, moisture (\%) and Number of Fruits per vine of cucumber at the time of last harvesting

\begin{tabular}{|c|c|c|c|c|c|c|}
\hline S.No. & Detail of Treatment & $\begin{array}{l}\text { Vine } \\
\text { length } \\
\text { (cm) }\end{array}$ & $\begin{array}{l}\text { No. of } \\
\text { branches } \\
\text { plant }^{-1}\end{array}$ & $\begin{array}{l}\text { Leaf } \\
\text { area } \\
\left(\mathrm{cm}^{2}\right)\end{array}$ & $\begin{array}{l}\text { Moisture } \\
(\%)\end{array}$ & $\begin{array}{l}\text { Number } \\
\text { of Fruits } \\
\text { per vine }\end{array}$ \\
\hline 1. & RDF (control) & 216.33 & 7.4 & 423.36 & 93.41 & 19.80 \\
\hline 2. & $\begin{array}{l}\text { RDF+ Humic acid } 10 \\
\mathrm{~kg} / \mathrm{ha} \text { (soil application) }\end{array}$ & 234.33 & 8.0 & 433.71 & 93.86 & 20.90 \\
\hline 3. & $\begin{array}{l}\text { RDF+ Humic acid } 0.1 \\
\% \text { (foliar spray) }\end{array}$ & 236.67 & 8.2 & 440.81 & 93.97 & 23.80 \\
\hline 4. & $\begin{array}{l}\text { RDF+ Humic acid } 10 \\
\mathrm{~kg} / \mathrm{ha}+\text { Humic acid } 0.1 \\
\% \text { (foliar spray) }\end{array}$ & 251.00 & 8.3 & 449.33 & 94.57 & 23.90 \\
\hline 5. & $\begin{array}{l}\text { RDF+ Humic acid } 10 \\
\mathrm{~kg} / \mathrm{ha}+\text { micronutrient } \\
\text { mixture (foliar spray) }\end{array}$ & 263.67 & 8.6 & 460.37 & 90.86 & 27.20 \\
\hline 6. & $\begin{array}{l}\text { RDF + Humic acid } \\
0.1 \%+\text { micronutrient } \\
\text { mixture (foliar spray) }\end{array}$ & 277.67 & 9.0 & 475.53 & 91.02 & 26.10 \\
\hline 7. & $\begin{array}{l}\text { RDF+ Humic acid } 10 \\
\mathrm{~kg} / \mathrm{ha}+\text { Humic } \\
\text { acid0.1\%+micronutrient } \\
\text { mixture }\end{array}$ & 304.33 & 9.0 & 484.91 & 92.86 & 30.10 \\
\hline 8. & CD 5\% & 12.13 & 0.5 & 36.04 & 3.16 & 0.74 \\
\hline
\end{tabular}

The effect of treatments on stem diameter also showed significant differences, where maximum value $(0.969 \mathrm{~cm})$ was recorded for RDF+ Humic acid $10 \mathrm{~kg} / \mathrm{ha}+$ Humic acid $0.1 \%+$ micronutrient mixture $\left(\mathrm{T}_{7}\right)$ followed by $\mathrm{T}_{5}(0.857 \mathrm{~cm})$ where as minimum value for this trait was observed for $\left(\mathrm{T}_{6}\right)$ $0.763 \mathrm{~cm}$. Men values for number of branches per vine and number of fruits per vine were also reported significantly higher for $\mathrm{T}_{7}$ i.e. 5.500 and 40.867 , respectively. These results are consistent with the previous findings of Fortun and Lopez, 1982; Adani et al., 1998; Hoang, 2003. They found that humates have positive effects on plant growth and positive effect of humic acid on the nutrients uptake was also proved with tomato, cucumber and other plants. Fruit weight and fruit length showed statistically significant effect of various treatment application having ranges of $98.933 \mathrm{~g}$ (control) to $109.267 \mathrm{~g}\left(\mathrm{~T}_{7}\right)$ and 15.357 $\mathrm{cm}\left(\mathrm{T}_{3}\right)$ to $18.303 \mathrm{~cm}\left(\mathrm{~T}_{7}\right)$, respectively. The effect of high humic acid treatment was also statistically significant for fruit volume and fruit diameter which showed maximum values for treatment $\mathrm{T}_{7}$. Fruit volume was ranges from $103.947 \mathrm{cc}\left(\mathrm{T}_{1}\right)$ to $114.857 \mathrm{cc}\left(\mathrm{T}_{7}\right)$ whereas fruit diameter was ranges from $2.547 \mathrm{~cm}\left(\mathrm{~T}_{3}\right)$ to 3.437 $\mathrm{cm}\left(\mathrm{T}_{7}\right)$. Moisture content showed non significant effect of treatments and did not showed any response of humic acid applications. Among all the treatments applied, significantly higher yield was obtained for $\mathrm{T}_{7}(3.810 \mathrm{~kg})$ followed by $\mathrm{T}_{5}$ $(3.710 \mathrm{~kg})$ as compare to minimum $(2.960 \mathrm{~kg})$ in control. These findings were in accordance with those obtained by Brownell et al., 1987; Yildirim, 2007; Karakurt et al., 2009. They reported that the foliar sprays of humic acid and micronutrients also promoted growth, and increased yield and quality in a number of plant species. Based on the above findings, it could be concluded that cucumber crop is highly responsive to humic acid application and yield can be significantly increased by applying humic acids both as soil application as well as by foliar spray. 


\section{References}

Adani, F., P. Genevini, P. Zaccheo and G. Zocchi. 1998. The effect of commercial humic acid on tomato plant growth and mineral nutrition. J. Plant Nutri., 21(3): 561-575.

Atiyeh, R.M., C.A. Edwards, J.D. Metzger, S. Lee and N.Q. Arancon. 2002. The influence of humic acids derived from earthwormprocessed organic wastes on plant growth. Biores. Technol., 84: 7-14.

Boehme, M., J. Schevtschenko and I. Pinker. 2005. Iron Supply of Cucumbers in Substrate Culture with Humate. Acta Hort. 697 ISHS, 41(1): 329-335.

Brownell, J.R., G. Nordstrom, J. Marihart and G. Jorgensen. 1987. Crop responses from two new leonardite extracts. Sci. Total Environ., 62: 491-499.

Cimrin, K.M. and I. Yilmaz. 2005. Humic acid applications to lettuce do not improve yield but do improve phosphorus availability. Acta Agriculturae Scandinavica, Section B, Soil and Plant Science, 55: 58-63.

Fortun, C. and C. Lopez. 1982. Influence of humic acid on the mineral nutrition and the development of the maize roots, cultivated in normal nutritive solutions and lacking of $\mathrm{Fe}$ and Mn. Anades-de Edafologiayagrobiologia (Spain). Jan-Feb/ 1982, 41(12): 335-349.

Halime, O.U., U. Husnu, K. Yasar and P. Huseyin. 2011. Changes in fruit yield and quality in response to foliar and soil humic acid application in cucumber. Scientific Res. Essays, 6(13): 2800-2803.

Hoang, T.L. 2003. Untersuchungen zur Wirkung von Huminsäure auf das Wachstum und die Nährstoffaufnahme von Tomaten (Lycopersicon esculentum MILL) und Wasserspinat (Ipomoea aquatic NORSSK). $\mathrm{PhD}$ Thesis, Humboldt- Universität zu Berlin, Landwirtschaftlich- Gärtnerische
Fakultät.

Kadans, J.M. 1978. Encyclopedia of Medical Foods, Thorns Pub. Ltd., Willing Borough, North.

Karakurt, Y., H. Unlu, H. Unlu and H. Padem. 2009. The influence of foliar and soil fertilization of humic acid on yield and quality of pepper. Acta Agriculturae Scandinavica Section B Plant Soil Sci., 59(3): 233- 237.

Kashif, W., Q.M. Kamran and M.S. Jilani. 2008. Effect of Different Nitrogen Levels on Growth and Yield of Cucumber (Cucumis sativus L.). J. Agric. Res., 46(3): 259-266.

Mah, S.Y. 1989. An effective fungicide for the control of downy mildew on cucumber. MAPPS

Muscolo, A., F. Bovalo, F. Gionfriddo and S. Nardi. 1999. Earthworm humic matter produces auxin-like effects on Daucus carota cell growth and nitrate metabolism. Soil Biol. Biochem., 31: 1303-1311.

Nandkarni, K.M. 1927. Indian materia medica. Nandkarni \& Co. Bombay. Newslett., 12(4): 40.

Pursglove, J.W. 1969. Tropical crops dicotyledons I. longamans. Green \& co. Ltd. London \& Harlow.

Serenella, N., D.A. Pizzeghelloa, N. Muscolob and A. Vianello. 2002. Physiological effects of humic substances on higher plants. Soil Biol. Biochem., 34: 1527-1536.

Tattini, M., A. Chiarini, R. Tafani and M. Castagneto. 1990. Effect of humic acids on growth and nitrogen uptake of containergrown olive (Olea europaea L. 'Maurino'). Internat. Symp. on Olive Growing, Proceeding, Wageningen (Netherlands), 125-128.

Yildirim, E. 2007. Foliar and soil fertilization of humic acid affect productivity and quality of tomato. Acta Agriculturae Scandinavica Section B-Soil, Plant Sci., 57: 182-186.

\section{How to cite this article:}

Somendra Meena, K.D. Ameta, R.A. Kaushik, Shankar Lal Meena and Madhu Singh. 2017. Performance of Cucumber (Cucucmis sativus L.) as Influenced by Humic Acid and Micro Nutrients Application under Polyhouse Condition. Int.J.Curr.Microbiol.App.Sci. 6(3): 1763-1767. doi: https://doi.org/10.20546/ijcmas.2017.603.202 